\title{
PENGUKURAN TINGKAT KEMATANGAN PRODUKTIVITAS OPERASIONAL DAN STAF PADA STMIK AKBA MAKASSAR
}

\author{
Erwin Gatot, Wisda \\ Teknik Komputer STMIK AKBA, Sistem Informasi STMIK AKBA \\ Email: erwin.gatot@gmail.com,wisda@akba.ac.id
}

\begin{abstract}
ABSTRAK
Peran teknologi informasi dalam pencapaian tujuan organisasi sangat berpengaruh. Demikian pula pada STMIK AKBA Makassar peran teknologi informasi merupakan salahsatu penunjang utama aktivitas operasional organisasi dalam memaksimalkan seluruh sumberdaya organisasi agar dapat bersinergi dengan penerapan teknologi informasi terkini hingga tercipta efesiensi dan efektifitas kinerja dilingkup STMIK AKBA Makassar.
\end{abstract}

Kata Kunci: IT Governance, COBIT, Maturity Models, STMIK AKBA

\section{ABSTRACT}

The role of information technology in the achievrmrnt of the organizational purpose is very imfluential. As well as STMIK AKBA Makassar, the role of information technology is one of the main proponent activity of the operational organization in maximizing all of the organizational resources in order to be able to synergize with the application of the latest information technology so that tothe efficiency and effectiveness of the performance at STMIK AKBA Makassar are actualized.

Keywords: IT Governance, COBIT, Maturity Models, STMIK AKBA

\section{Pendahuluan}

\subsection{Latar Belakang}

Teknologi informasi merupakan bagian yang tak terpisahkan dari STMIK AKBA sebagai sekolah tinggi yang berkonsentrasi pada ilmu komputer, teknologi informasi juga merupakan bagian yang sangat vital dalam menunjang segala kegiatan operasional STMIK AKBA baik dalam proses belajar mengajar maupun dalam manajemen administrasi organisasi, sebagai salahsatu sentral penunjang kegiatan - kegiatan operasional organisasi dalam pencapaian visi-misi tentu keberadaan teknologi informasi terkini tidaklah dapat mencapai tingkat efisiensi dan efektifitas kinerja tanpa di tunjang dengan kemampuan sumber daya lainnya di lingkup organisasi baik internal ataupun eksternal terkhusus pada sumber daya manusia, maka untuk mengetahui sejauh mana tingkat kematangan operasional produktifitas dan staf terhadap keberadaan teknologi informasi di lingkup organisasi STMIK AKBA diperlukan suatu pengukuran tingkat kematangan dengan menggunakan COBIT 4.1 yang dengan audit ini diharapkan ada kemajuan yang signifikan terhadap organisasi.

\subsection{Tujuan dan Manfaat Penelitian}

Tujuan penelitian adalah untuk mengukur tingkat kematangan perencanaan dan penerapan teknologi informasi di internal organisasi STMIK AKBA Makassar, memberikan kesimpulan 
dan saran untuk manajemen internal organisasi. adapun manfaat penelitian ini adalah bagaimana manajemen organisasi STMIK AKBA Makassar dapat mengetahui apakah penerapan teknologi informasi yang telah ada mampu menunjang tujuan bisnis organisasi, untuk mengetahui tingkat kapabilitas tata kelola teknologi informasi dilingkup organisasi STMIK AKBA Makassar, menemukan kesenjagan (gap analysis) dalam penerapan teknologi informasi pada STMIK AKBA Makassar, memberikan saran dan masukan pada STMIK AKBA Makassar bagaimana bisa lebih mengefektifkan dan mengefesienkan penerapan tata kelola teknologi informasi dengan tingkat kematangan yang sesuai standarisasi COBIT 4.1

\section{Tinjauan Pustaka}

\subsection{Dasar Teori}

a. Cobit 4.1

COBIT (Control Objectives for Information and Related Technology) adalah sebuah kerangka yang diperkenalkan oleh ISACA dan ITGI untuk penerapan IT GOVERNANCE, Cobit dibuat untuk menjembatani antara resiko bisnis, kebutuhan kontrol, serta permasalahan - permasalahan teknis bagi para auditor, manajemen, dan pengguna. Kerangka kerja COBIT mengidentifikasi 34 proses TI yang di kelompokkan kedalam 4 domain utama, yaitu domain Plan and Organize (PO), Acquire and Implement (AI), Deliver and Support (DS), dan Monitor and Evaluate (ME). Suatu informasi yang berkualitas dapat dihasilkan dari rangkaian COBIT ini dalam bentuk rangkaian aktivitas manajemen dimana 4 domain utama :

1. Planning and Organisation (PO)

2. Acquisition and Implementation (AI)

3. Delevery and Support (DS)

4. Monitoring and Evaluation (ME) dan terdiri dari 34 proses serta 210 control objective.

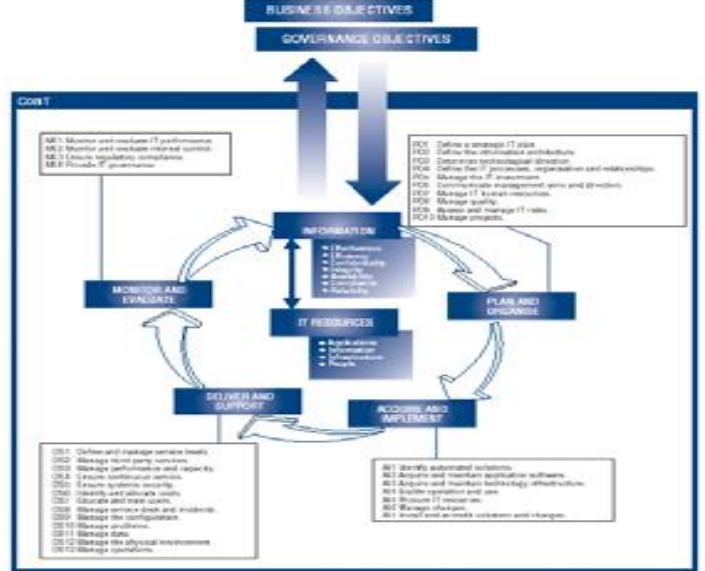

Gambar 1. Framework Cobit

Cobit dapat digunakan sebagai IT Govenance tools, dan juga membantu perusahaan mengoptimalkan investasi TI mereka. Hala terpenting lainnya, COBIT dapat juga dijadikan sebagai acuan atau referensi apabila terjadi suatu kesimpang siuran dalam penerapan teknologi (audit TI) oleh INternal Auditor, dapat dimulai dengan menentukan area-area yang relevan dan berisiko paling tinggi, melalui analisa atas ke-34 proses tersebut. Sementara untuk kebutuhan penugasan tertentu, misalnya audit atas proyek TI, dapat dimulai dengan memilih proses yang relevan dari proses-proses tersebut (Henczel, 2001). Selain dapat digunakan oleh auditor, COBIT dapat juga digunakan oleh manajemen sebagai jembatan antara risiko-risiko TI dengan pengendalian yang dibutuhkan (IT risk management) dan juga referensi utama yang sangat membantu dalam penerapan IT Governance di perusahaan (COBIT, 2003).

\section{b. Maturity Model}

IT Maturity Model merupakan model yang digunakan untuk mengukur tingkat kematangan pengelolaan teknologi informasi dalam suatu organisasi. Model pengukuran ini mengadopsi Capability Maturity model untuk perangkat lunak yang dipublish Software Engeneering Institute, Carniege Mellon University. IT Maturity Model terdiri dari lima tingkat kematangan pengelolaan IT, meliputi : 
tinggkat 0 (non-existent), tingkat 1 (initial), tingkat 2 (repeateable), tingkat 3 (defined), tingkat 4 (managed) dan tingkat 5 (optimised). Semakin tinggi maturity level akan semakin baik proses pengelolaan teknologi informasi, yang secara tidak langsung bermakna semakin reliable dukungan teknologi informasi dalam proses pencapaian tujuan organisasi. (Megawati , Fauzi Amrullah,2014).

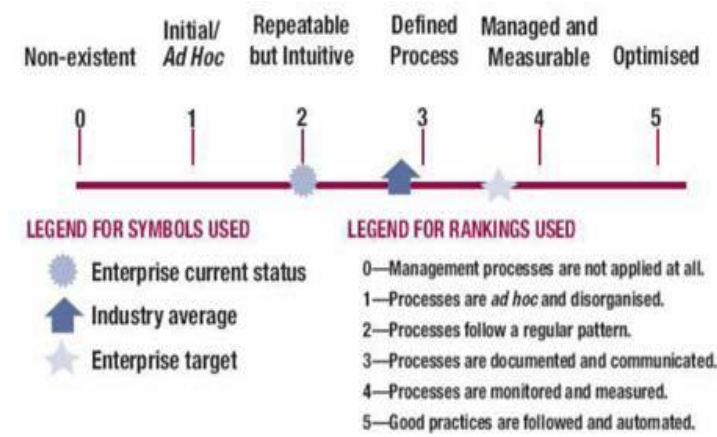

Gambar 2. Maturity Model

1). Level 0 (Non-existent)

Perusahaan tidak mengetahui sama sekali proses teknologi informasi di perusahaannya. (Megawati , Fauzi Amrullah,2014).

2). Level 1 (Initial Level)

Pada level ini, organisasi pada umumnya tidak menyediakan lingkungan yang stabil untuk mengembangkan suatu produk baru. Ketika suatu organisasi kelihatannya mengalami kekurangan pengalaman manajemen, keuntungan dari mengintegrasikan pengembangan produk tidak dapat ditentukan dengan perencanaan yang tidak efektif, respon sistem. Proses pengembangan tidak dapat diprediksi dan tidak stabil, karena proses secara teratur berubah atau dimodifikasi selama pengerjaan berjalan beberapa form dari satu proyek ke proyek lain. Kinerja tergantung pada kemampuan individual atau term dan variasi dengan keahlian yang dimilikinya. (Megawati , Fauzi Amrullah,2014).
3). Level 2 (Repeatable Level)

Pada level ini, kebijakan untuk mengatur pengembangan suatu proyek dan prosedur dalam mengimplementasikan kebijakan tersebut ditetapkan. Tingkat efektif suatu proses manajemen dalam mengembangankan proyek adalah institutionalized, dengan memungkinkan organisasi untuk mengulangi pengalaman yang berhasil dalam mengembangkan proyek sebelumnya, walaupun terdapat proses tertentu yang tidak sama. Tingkat efektif suatu proses mempunyai karakteristik seperti; practiced, dokumentasi, enforced, trained, measured, dan dapat ditingkatkan. Product requirement dan dokumentasi perancangan selalu dijaga agar dapat mencegah perubahan yang tidak diinginkan. (Megawati, Fauzi Amrullah, 2014).

4). Level 3 (Defined Level)

Pada level ini, proses standar dalam pengembangan suatu produk baru didokumentasikan, proses ini didasari pada proses pengembangan produk yang telah diintegrasikan. Prosesproses ini digunakan untuk membantu manejer, ketua tim dan anggota tim pengembangan sehingga bekerja dengan lebih efektif. Suatu proses yang telah didefenisikan dengan baik mempunyai karakteristik; readiness criteria, inputs, standar dan prosedur dalam mengerjakan suatu proyek, mekanisme verifikasi, output dan kriteria selesainya suatu proyek. Aturan dan tanggung jawab yang didefinisikan jelas dan dimengerti. Karena proses perangkat lunak didefinisikan dengan jelas, maka manajemen mempunyai pengatahuan yang baik mengenai kemajuan proyek tersebut. Biaya, jadwal dan kebutuhan proyek dalam pengawasan dan kualitas produk yang diawasi. (Megawati, Fauzi Amrullah,2014). 
5). Level 4 (Managed Level)

Pada level ini, organisasi membuat suatu matrik untuk suatu produk, proses dan pengukuran hasil. Proyek mempunyai kontrol terhadap produk dan proses untuk mengurangi variasi kinerja proses sehingga terdapat batasan yang dapat diterima. Resiko perpindahan teknologi produk, prores manufaktur, dan pasar harus diketahui dan diatur secara hati-hati. Proses pengembangan dapat ditentukan karena proses diukur dan dijalankan dengan limit yang dapat diukur. (Megawati, Fauzi Amrullah,2014).

6). Level 5 (Optimized Level)

Pada level ini, seluruh organisasi difokuskan pada proses peningkatan secara terusmenerus. Teknologi informasi sudah digunakan terintegrasi untuk otomatisasi proses kerja dalam perusahaan, meningkatkan kualitas, efektifitas, serta kemampuan beradaptasi perusahaan. Tim pengembangan produk menganalisis kesalahan dan defects untuk menentukan penyebab kesalahannya. Proses pengembangan melakukan evaluasi untuk mencegah kesalahan yang telah diketahui dan defects agar tidak terjadi lagi. (Megawati, Fauzi Amrullah,2014).

\subsection{Kajian Pustaka}

Penelitian Nurhayani dengan judul "Perancangan Tata Kelola Teknologi Informasi Pada Layanan Akademik di Amik Sigma Palembang Menggunakan Analisis SWOT dan COBIT" (Jurnal SIGMATA : LPPM AMIK SIGMA Volume 1 : Nomor : 2 Edisi : April 2013 September 2013). Sumber daya yang perlu dikelola oleh organisasi, yaitu : (1). informasi : Informasi diperoleh dari hasil pengelolaan data, (2). Infrastruktur : infrastruktur meliputi fasilitas maupun teknologi yang ada pada organisasi sebagai pendukung dalam melakukan fungsi bisnis utamanya. Teknologi yang digunakan pada umumnya sudah mengikuti perkembangan teknologi saat ini tetapi belum memiliki standar baku dalam penggunaannya sehingga belum dapat membantu pengguna dalam memperoleh informasi yang berkualitas secara maksimal, (3). Sistem aplikasi : sistem aplikasi yang ada belum memiliki standar operasi atau prosedur yang baku dalam penggunaannya serta belum terintegrasi secara menyeluruh, karena masih adanya pandangan dimana masing-masing bagian kerja hanya menangani sistem informasi yang berkaitan dengan bagian kerjanya saja serta belum terhubungnya sistem basis data yang digunakan, (4). Manusia : sumber daya manusia pada organisasi sebagian besar belum memahami dan menggunakan aplikasiaplikasi yang ada serta teknologi yang tersedia.

Dalam penelitian Bagus Apri Susandi yang berjudul "Audit Tata Kelola Teknologi Informasi Menggunakan COBIT 4.1 Pada PTPN VII Unit Usaha Betung" (Jurnal Teknik Informatika Universitas Bina Darma Palembang Maret 2014) Audit teknologi informasi adalah bentuk pengawasan dan pengendalian dari infrastruktur teknologi informasi secara menyeluruh. Audit teknologi informasi dapat berjalan bersama-sama dengan audit finansial dan audit internal, atau kegiatan pengawasan dan evaluasi lain yang sejenis.

Penelitian Megawati , Fauzi Amrullah, dengan judul "Evaluasi Tingkat Kematangan Teknologi Informasi Dengan Menggunakan Model Maturity Level COBIT 4.1 (Studi Kasus PT. BRI Cabang Bangkiang)", (Jurnal Sains, Teknologi dan Industri, Vol. 12, No. 1, Desember 2014). Permasalahan yang terjadi di lingkungan PT.BRI khususnya pada divisi Teknologi Informasi adalah pelaksanaan kinerja Teknologi Informasi belum maksimal, hal ini disebabkan karena pergantian kepemimpinan yang sering terjadi. Selain itu kurangnya pengetahuan untuk menilai kualitas software yang digunakan sehingga tidak diketahui apakah aplikasi yang 
digunakan efektif dan efisien untuk proses bisnis yang ada.

Dan juga dalam penelitian Gatot dengan judul "Audit Tata Kelola Produktivitas Operasional dan Staf (Studi Kasus : Distrik Navigasi Kelas I Makassar)" (Journal Speed - Sentra Pendidikan Engineering dan Edukasi, Voleme 8 No.1 Tahun 2016). Disimpulkan bahwa tatakelola teknologi informasi untuk domain Improve and maintain operational and staff productivity Distrik Navigasi kelas I Makassar berada pada level 2 atau repeatable.

\section{Metode Penelitian}

\subsection{Pengumpulan Data}

Metode yang digunakan dalam penelitian ini untuk mendapatkan data dan informasi maka metode yang digunakan dalam pengumpulan data sebagai berikut :

a. Obeservasi

Dalam hal ini yang di observasi tentang tingkat kematangan perencanaan dan penerapan teknologi informasi di internal organisasi STMIK AKBA Makassar.

b. Studi Pustaka

Metode yang dilakukan adalah dengan cara mencari bahan yang mendukung penelitian ini melalui jurnal baik onlinen maupun print dan buku yang erat kaitannya dengah masalah penelitian ini.

c. Wawancara

Metode ini yang dilakukan peneliti adalah melakukan tanya jawab langsung dengan unsur pimpinan dan staf yang ada di STMIK AKBA Makassar.

d. Kuesioner

Pada metode ini kegiatan yang dilakukan adalah membuat pernyataan/pertanyaan berdasarkan framework cobit 4.1 untuk mengetahui tingkat kematangan perencanaan dan penerapan teknologi informasi di internal organisasi STMIK AKBA Makassar.

\subsection{Pengolahan Data}

Setelah melakukan pengumpulan data maka untuk mengetahui tingkat kematangan perencanaan dan penerapan teknologi informasi di internal organisasi STMIK AKBA Makassar, proses yang dilakukan adalah melakukan komparasi pada setiap proses TI generic yang telah didefinisikan dalam kerangka kerja cobit dengan kondisi yang yang berjalan di STMIK AKBA Makassar.

a. Penentuan IT Goals

Memetakan tujuan bisnis pada improve and maintain operational and staff productivity terdapat 4 IT Goals :

1). Aqquire and maintain integrated and standardised application system(7).

2). Aqquire and maintain an integrated and standardised IT infrastructure(8).

3). Ensure seamless integration of application into business prosess(11).

4). Ensure proper use and performance of the application and technology solutions (13).

b. Core IT

1). PO2 - Define the Information Architecture.

Proses ini meningkatkan kualitas pengambilan keputusan manajemen dengan memastikan bahwa informasi yang dapat dipercaya dan aman disediakan, dan memungkinkan sumber daya rasionalisasi sistem informasi untuk tepat sesuai dengan strategi bisnis.

2). PO3 - Determine Technological Direction.

Pengaturan rencana yang terus diperbaharui mencakup aspekaspek seperti arsitektur sistem, arah teknologi, rencana akuisisi, standar, strategi migrasi dan kontingensi.

3). PO6 - Communicate Management Aims and Direction.

Program komunikasi yang berkelanjutan dilaksanakan untuk mengartikulasikan misi, tujuan layanan, kebijakan dan prosedur, 
dll, disetujui dan didukung oleh manajemen.

4). AI2 - Acquire and Maintain Application Software.

Proses ini meliputi desain aplikasi, pemuatan kontrol aplikasi dan persyaratan keamanan, dan pengembangan dan konfigurasi sesuai dengan standar.

5). AI3 - Acquire and Maintain Technology Infrastructure.

Pendekatan yang direncanakan untuk akuisisi, pemeliharaan dan perlindungan infrastruktur sejalan dengan yang telah disepakati strategi teknologi dan penyediaan pengembangan dan uji lingkungan.

6). AI4 - Enable Operation and Use.

Proses ini membutuhkan produksi dokumentasi dan manual bagi pengguna dan IT, dan menyediakan pelatihan untuk memastikan penggunaan yang tepat dan pengoperasian aplikasi dan infrastruktur.

7). AI5 - Procure IT Resources.

Sumber daya TI, termasuk orang, hardware, software dan layanan, perlu diperoleh.

8). AI7 - Install and Accredit Solutions and Changes.

Membutuhkan pengujian yang tepat dalam lingkungan khusus dengan data yang relevan tes, definisi peluncuran dan migrasi petunjuk, perencanaan rilis dan promosi yang sebenarnya untuk produksi, dan review pasca implementasi.

9). DS7 - Educate and Train Users.

Pendidikan yang efektif dari semua pengguna sistem TI, termasuk dalam IT, membutuhkan identifikasi kebutuhan pelatihan masing-masing kelompok pengguna. Selain kebutuhan mengidentifikasi, proses ini termasuk mendefinisikan dan melaksanakan strategi untuk pelatihan yang efektif dan mengukur hasil. Program pelatihan yang efektif meningkatkan penggunaan teknologi yang efektif dengan mengurangi kesalahan pengguna, meningkatkan produktivitas dan meningkatkan kepatuhan dengan kontrol utama, seperti langkah-langkah keamanan pengguna.

10). DS8 - Manage Service Desk and Incidents.

Pendidikan yang efektif dari semua pengguna sistem TI, termasuk dalam IT, membutuhkan identifikasi kebutuhan pelatihan masing-masing kelompok pengguna. Selain kebutuhan mengidentifikasi, proses ini termasuk mendefinisikan dan melaksanakan strategi untuk pelatihan yang efektif dan mengukur hasil. Program pelatihan yang efektif meningkatkan penggunaan teknologi yang efektif dengan mengurangi kesalahan pengguna, meningkatkan produktivitas dan meningkatkan kepatuhan dengan kontrol utama, seperti langkah-langkah keamanan pengguna.

Tabel 1 : Form Isian Penilian

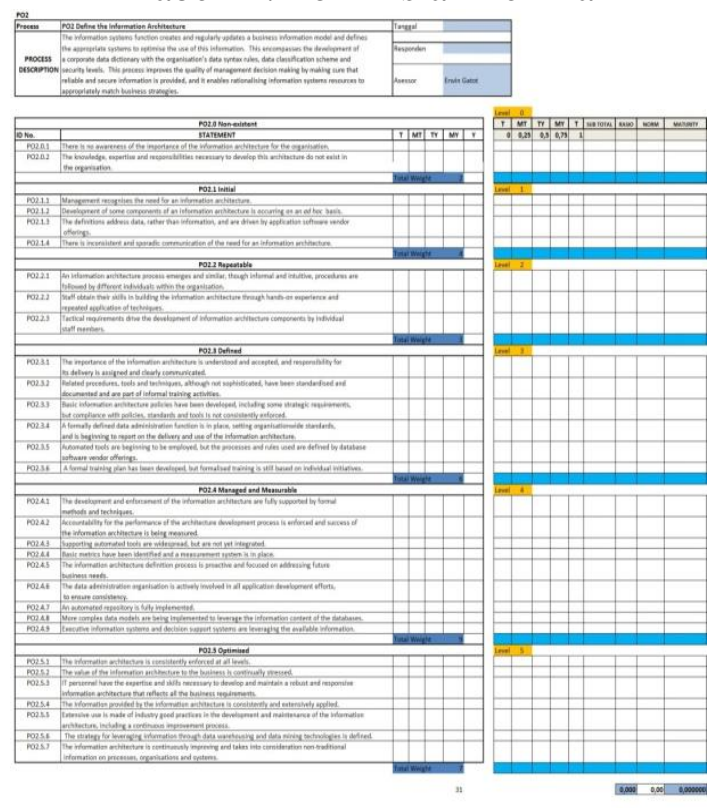


Mengisi form assisment dari level-level pernyataan pada setiap proses dengan menentukan nilai bobot dari setiap jawaban :

- $\mathrm{T}$ (Tidak) $=0$

- MT (Mungkin Tidak) $=0,25$

- $\mathrm{TY}$ (Tidak Yakin) $=0,5$

- $\mathrm{MY}$ (Mungkin Ya) $=0,75$

- $\mathrm{Y}$ (Ya) $=1$

Langkah-langkah penghitungan tingkat kematangan dari setiap proses :

Penghitungan indeks

Indeks $\mathrm{A}=$ Level Kematangan

Indeks B $=$ Sub Total

Indeks $\mathrm{C}=$ Jumlah Pernyataan/Pertanyaan

Indeks $\mathrm{D}=$ Rasio

Index $\mathrm{E}=$ Normalisasi

Indeks $B=\sum$ Indeks $C$

Indeks $D=\frac{\text { Indeks } B}{\text { Indeks } C}$

Indeks $E=\frac{\text { Indeks } D}{\sum \text { Indeks } D}$

Maturity $=$ Indeks $E *$ Indeks $A$

Butir-butir periksa kemudian akan diberikan penilaian dengan standar penilaian yang ada pada standar COBIT pada butir periksa ini, dengan kriteria sebagai berikut:

- 5 = Optimize

- 4 = Diatur dan Dapat Diukur

- $3=$ Proses Ditetapkan

$-2=$ Terdefinisi

- 1 = Tidak Kenal

\section{Implementasi dan Hasil}

Hasil dari tingkat kematangan tata kelola teknologi informasi pada STMIK AKBA Makassar memfokuskan audit pada Improve and maintain operational and staff productivity yang mana terdiri dari 10 proses dari 3 domain (Planning and Organisation, Acquisition and
Implementation, Delivery and Support) telah di dapatkan hasil yang di gambarkan pada tabel - tabel berikut :

Tabel 2 : Indeks Kematangan PO2

\begin{tabular}{|c|c|c|c|c|c|}
\hline Itaturing Leet & $\begin{array}{c}\text { Sum or Statement } \\
\text { Compliance } \\
\text { Values }\end{array}$ & $\begin{array}{c}\text { Number of } \\
\text { Mataity Leel } \\
\text { Statements }\end{array}$ & \begin{tabular}{|c|} 
Ifanrily Lenel \\
Compliance \\
Values
\end{tabular} & $\begin{array}{l}\text { Nornulized } \\
\text { Compliance } \\
\text { Values }\end{array}$ & $\begin{array}{l}\text { Contrintitinn } \\
\text { (mituring) }\end{array}$ \\
\hline 0 & 1,50 & 2 & 0,75 & 0,16 & \\
\hline 1 & 3,75 & 4 & 0,94 & 0,19 & 0,194085 \\
\hline 2 & 2,30 & 3 & 0,83 & 0,17 & 0,345040 \\
\hline 3 & 5,00 & 6 & 0,83 & 0,17 & 0,517960 \\
\hline 4 & 5,25 & 9 & 0,58 & 0,12 & 0,483056 \\
\hline 5 & 6,25 & 7 & 0,89 & 0,18 & 0,924214 \\
\hline Total & & & 4,83 & 1,00 & 2,463956 \\
\hline
\end{tabular}

Tabel 3 : Indeks Kematangan PO3

\begin{tabular}{|c|c|c|c|c|c|}
\hline Ilaturiţ̧ Letel & $\begin{array}{l}\text { Sum O1 Ot Sutement } \\
\text { Compliance } \\
\text { Values }\end{array}$ & $\begin{array}{l}\text { Number of } \\
\text { Matain Leal } \\
\text { Satements }\end{array}$ & $\begin{array}{l}\text { Mrturity Letel } \\
\text { Complianee } \\
\text { Values }\end{array}$ & $\begin{array}{l}\text { Sormalized } \\
\text { Camplianat } \\
\text { Values }\end{array}$ & $\begin{array}{l}\text { Costribution } \\
\text { (meturity) }\end{array}$ \\
\hline 0 & 2.25 & 3 & 0,75 & 0,18 & \\
\hline 1 & 3,75 & 5 & 0,75 & 0.18 & 0,180982 \\
\hline 2 & 3,75 & 5 & 0,75 & 0,18 & 0,361965 \\
\hline 3 & 4,25 & 6 & 0,71 & 0,17 & 0,512784 \\
\hline 4 & 6,30 & 10 & 0,65 & 0,16 & 0,627406 \\
\hline 5 & 3,75 & 7 & 0,54 & 0,13 & 0,646366 \\
\hline Total & & & & 1,00 & 2,329503 \\
\hline
\end{tabular}

Tabel 4 : Indeks Kematangan PO6

\begin{tabular}{|c|c|c|c|c|c|}
\hline Ilaturity Leel & $\begin{array}{c}\text { Sum } 0 \text { Of Satement } \\
\text { Compliance } \\
\text { Values }\end{array}$ & \begin{tabular}{|c|c|} 
Number of \\
Mlataily Leat \\
Statements \\
\end{tabular} & $\begin{array}{l}\text { Naturitr Leetl } \\
\text { Compliance } \\
\text { Values }\end{array}$ & $\begin{array}{c}\text { Normulized } \\
\text { Complinace } \\
\text { Values } \\
\end{array}$ & $\begin{array}{l}\text { Conthatoint } \\
\text { (miturity) }\end{array}$ \\
\hline 0 & 2,00 & 2 & 1,00 & 0,00 & \\
\hline 1 & 2.50 & 3 & 0,83 & 0,19 & 0,191912 \\
\hline 2 & 2,25 & 3 & 0,75 & 0,17 & 0,345442 \\
\hline 3 & 5,75 & 7 & 0,82 & 0,19 & 0,567512 \\
\hline 4 & 3.25 & 4 & 0.25 & 0,06 & 0,230295 \\
\hline 5 & 2,75 & 4 & 0,69 & 0,16 & 0,791638 \\
\hline Total & & & 4,34 & 0,77 & 2,126799 \\
\hline
\end{tabular}

Tabel 5 : Indeks Kematangan AI2

\begin{tabular}{|c|c|c|c|c|c|}
\hline Mlaturiţ Letel & $\begin{array}{c}\text { Sum Of Satement } \\
\text { Counpliante } \\
\text { Values }\end{array}$ & $\begin{array}{l}\text { Number of } \\
\text { Matairy Leeel } \\
\text { Statements }\end{array}$ & $\begin{array}{l}\text { Masturity Lenel } \\
\text { Compliase } \\
\text { Values }\end{array}$ & $\begin{array}{l}\text { Nornalized } \\
\text { Compliance } \\
\text { Values }\end{array}$ & $\begin{array}{c}\text { Contrhilatien } \\
\text { (maturity) }\end{array}$ \\
\hline 0 & 1,75 & 2 & 0,88 & 0,20 & 0 \\
\hline 1 & 2,75 & 3 & 0,92 & 0,20 & 0,204651 \\
\hline 2 & 3,25 & 4 & 0,81 & 0,18 & 0,362791 \\
\hline 3 & 2,50 & 5 & 0,50 & 0,11 & 0,334884 \\
\hline 4 & 1,75 & 3 & 0,58 & 0,13 & 0,520930 \\
\hline 5 & 4,75 & 6 & 0,79 & 0,18 & 0,883721 \\
\hline Total & & & 4,48 & 1,00 & 2,306977 \\
\hline
\end{tabular}

Tabel 6 : Indeks Kematangan AI3

\begin{tabular}{|c|c|c|c|c|c|}
\hline Maturity̆ Let & $\begin{array}{l}\text { Sum Of Statement } \\
\text { Couppliance } \\
\text { Vilues }\end{array}$ & $\begin{array}{c}\text { Number of } \\
\text { Natairy Leel } \\
\text { Statements }\end{array}$ & $\begin{array}{l}\text { Maturith Letel } \\
\text { Compliance } \\
\text { Values }\end{array}$ & $\begin{array}{l}\text { Nornulized } \\
\text { Complinnce } \\
\text { Vilues }\end{array}$ & $\begin{array}{l}\text { Contriblitin } \\
\text { (maturity) }\end{array}$ \\
\hline 0 & 1,00 & 2 & 1,00 & 0,38 & \\
\hline 1 & 3,25 & 3 & 0,81 & 0,31 & 0,437956 \\
\hline 2 & 3,50 & 4 & 0,70 & 0,27 & 0,538462 \\
\hline 3 & 3,00 & 5 & 0,60 & 0,23 & 0,692308 \\
\hline 4 & 2,50 & 3 & 0.28 & 0,11 & 0,427350 \\
\hline 5 & 2,25 & 6 & 0,38 & 0,14 & 0,721154 \\
\hline Total & & & 2,60 & 1,00 & 2,817230 \\
\hline
\end{tabular}


Tabel 7 : Indeks Kematangan AI4

\begin{tabular}{|c|c|c|c|c|c|}
\hline Maturiny Leet & $\begin{array}{l}\text { Sum Of Statenten } \\
\text { Campliance } \\
\text { Values }\end{array}$ & $\begin{array}{c}\text { Number of } \\
\text { Ilatairy Leel } \\
\text { Statenents }\end{array}$ & $\begin{array}{l}\text { Maturity Letel } \\
\text { Campliance } \\
\text { Values }\end{array}$ & $\begin{array}{l}\text { Nornulized } \\
\text { Compliance } \\
\text { Values }\end{array}$ & $\begin{array}{l}\text { Contrivetien } \\
\text { (maturity) }\end{array}$ \\
\hline 0 & 1,25 & 2 & 0,63 & 0,15 & \\
\hline 1 & 5,75 & 6 & 0,96 & 0,23 & 0,227273 \\
\hline 2 & 3,75 & 3 & 0,75 & 0,18 & 0,335731 \\
\hline 3 & 5,25 & 9 & 0,58 & 0,14 & 0,415020 \\
\hline 4 & 6,75 & 10 & 0,68 & 0,16 & 0,640316 \\
\hline 5 & 2,5 & 4 & 0,63 & 0,15 & $\begin{array}{l}0,741107 \\
\end{array}$ \\
\hline Total & & & 4,217 & 1,00 & 2.379447 \\
\hline
\end{tabular}

Tabel 8 : Indeks Kematangan AI5

\begin{tabular}{|c|c|c|c|c|c|}
\hline Shatrity Letet & 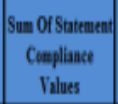 & $\begin{array}{c}\text { Nimber of } \\
\text { Ilatuit heal } \\
\text { Saturents }\end{array}$ & 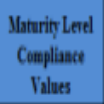 & $\begin{array}{l}\text { Nornalized } \\
\text { Complinat } \\
\text { Values }\end{array}$ & 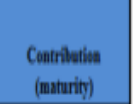 \\
\hline 0 & 1,75 & 2 & 0.88 & 0,21 & \\
\hline 1 & 2,75 & 4 & 0,69 & 0.17 & 0,160028 \\
\hline 2 & 4,25 & 6 & 0,71 & 0,17 & 0,344179 \\
\hline 3 & 4,00 & 6 & 0,67 & 0.16 & 0,485900 \\
\hline 4 & 3,79 & 9 & 0.54 & 0,13 & $0,52060^{\circ}$ \\
\hline 3 & 4,5 & 7 & 0,64 & 0,16 & 0,780911 \\
\hline Total & & & 4,116 & 1,00 & 2,298626 \\
\hline
\end{tabular}

Tabel 9 : Indeks Kematangan AI7

\begin{tabular}{|c|c|c|c|c|c|}
\hline Maturiţ Leetl & $\begin{array}{l}\text { Sum Of Satement } \\
\text { Cumpliance } \\
\text { Values }\end{array}$ & $\begin{array}{c}\text { Number of } \\
\text { Mlatioiry Leel } \\
\text { Statements }\end{array}$ & $\begin{array}{l}\text { Maturity Leel } \\
\text { Compliance } \\
\text { Values }\end{array}$ & $\begin{array}{l}\text { Nornulized } \\
\text { Complianee } \\
\text { Vilues }\end{array}$ & $\begin{array}{l}\text { Contribation } \\
\text { (mintrity) }\end{array}$ \\
\hline 0 & 0,75 & 1 & 0,75 & 0,16 & 0,00 \\
\hline 1 & 2.50 & 3 & 0,83 & 0,18 & 0,18 \\
\hline 2 & 2,25 & 3 & 0,75 & 0,16 & 0,33 \\
\hline 3 & 3,00 & 4 & 0,75 & 0,16 & 0,49 \\
\hline 4 & 6,00 & 8 & 0,75 & 0,16 & 0,65 \\
\hline 5 & 3 & 4 & 0,75 & 0,163636364 & 0,818181818 \\
\hline Total & & & 4,583 & 1,00 & 2,472727 \\
\hline
\end{tabular}

Tabel 10 : Indeks Kematangan DS7

\begin{tabular}{|c|c|c|c|c|c|}
\hline Jaturuing Letel & $\begin{array}{l}\text { Sun } 01 \text { S Sutenten } \\
\text { Compliance } \\
\text { Vilues }\end{array}$ & 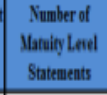 & 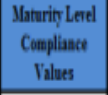 & $\begin{array}{l}\text { Sornulized } \\
\text { Coupliance } \\
\text { Values } \\
\end{array}$ & $\begin{array}{l}\text { Contrihationa } \\
\text { (maturity) }\end{array}$ \\
\hline 0 & 1,50 & 2 & 0,75 & 0,17 & 0,00 \\
\hline 1 & 3,00 & 4 & 0,75 & 0,17 & 0,17 \\
\hline 2 & 3,50 & 3 & 0,70 & 0,16 & 0,32 \\
\hline 3 & 4,25 & 5 & 0,85 & 0,19 & 0,58 \\
\hline 4 & 5,00 & 8 & 0,63 & 0,14 & 0,59 \\
\hline 5 & 5,75 & 8 & 0,72 & 0,16 & 0,82 \\
\hline Total & & & 4,394 & 1,00 & 2,456615 \\
\hline
\end{tabular}

Tabel 11: Indeks Kematangan DS8

\begin{tabular}{|c|c|c|c|c|c|}
\hline Ulaturity Leel & 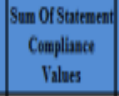 & $\begin{array}{l}\text { Number of } \\
\text { Nitaniy Leat } \\
\text { Statements } \\
\end{array}$ & $\begin{array}{l}\text { Mthurity Letel } \\
\text { Compliance } \\
\text { Vilues }\end{array}$ & $\begin{array}{l}\text { Sormulized } \\
\text { Compliance } \\
\text { Vilues }\end{array}$ & $\begin{array}{c}\text { Catrintution } \\
\text { (uturity) }\end{array}$ \\
\hline 0 & 2,25 & 3 & 0,75 & 0,17 & 0,00 \\
\hline 1 & 3,75 & 4 & 0.94 & 0.21 & 0.21 \\
\hline 2 & 2,75 & 4 & 0,69 & 0,16 & 0,31 \\
\hline 3 & 4,75 & 7 & 0,68 & 0,16 & 0,47 \\
\hline 4 & 4.26 & 6 & 0,71 & 0.16 & 0,65 \\
\hline 5 & 4,25 & 7 & 0,607142857 & 0,138964578 & 0,694828888 \\
\hline Total & & & 4,369 & 1,00 & 2,338556 \\
\hline
\end{tabular}

Tabel 12 : Bobot Rata-Rata

\begin{tabular}{|r|r|l|r|}
\hline No & \multicolumn{2}{|c|}{ Control Objoctive } & Maturity Loval \\
\hline 1 & PO2 & Define the Information Architecture & 2,46 \\
\hline 2 & PO3 & Determine Technological Direction & 2,33 \\
\hline 3 & PO6 & Communicate Management Aims and Direction & 2,13 \\
\hline 4 & A12 & Acquire and Maintain Application Software & 2,31 \\
\hline 5 & A13 & Acquire and Maintain Techinology Infrastructure & 2,82 \\
\hline 6 & A44 & Enable Operation and Use & 2,38 \\
\hline 7 & A15 & Procure IT Resources & 2,30 \\
\hline 8 & A17 & Install and Accredit Solutions and Changes & 2,47 \\
\hline 9 & DS7 & Educate and Train Users & 2,46 \\
\hline 10 & DS8 & Manage Service Desk and Incidents & 2,34 \\
\hline
\end{tabular}

Tabel 13 : Tingkat Kematangan dan GAP

\begin{tabular}{|r|r|r|r|r|}
\hline No & Control Objectives & Maturity Level & Minimum & Maximum \\
\hline 1 & PO2 & 2,46 & 3,5 & 5 \\
\hline 2 & PO3 & 2,33 & 3,5 & 5 \\
\hline 3 & PO6 & 2,13 & 3,5 & 5 \\
\hline 4 & A12 & 2,31 & 3,5 & 5 \\
\hline 5 & A13 & 2,82 & 3,5 & 5 \\
\hline 6 & A14 & 2,38 & 3,5 & 5 \\
\hline 7 & A15 & 2,30 & 3,5 & 5 \\
\hline 8 & A17 & 2,47 & 3,5 & 5 \\
\hline 9 & DS7 & 2,46 & 3,5 & 5 \\
\hline 10 & D58 & 2,34 & 3,5 & 5 \\
\hline
\end{tabular}

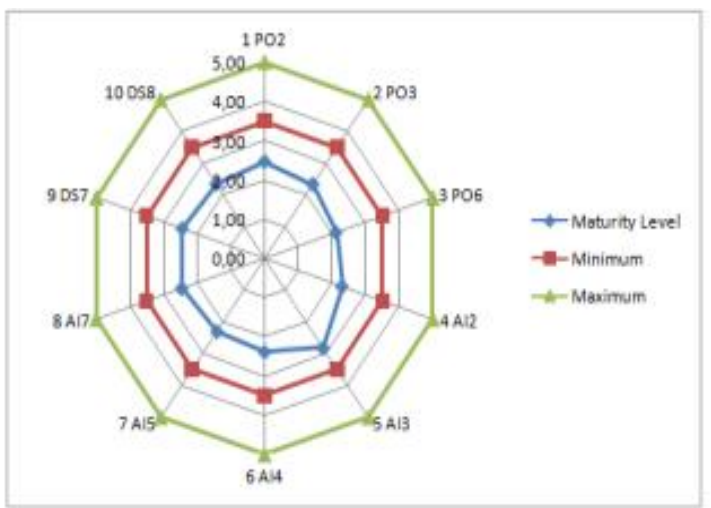

Gambar 3. Current dan Expectacy user

\section{Kesimpulan dan Saran}

\subsection{Kesimpulan}

Setelah melalukan proses audit pada STMIK AKBA Makassar untuk Improve and maintain operational and staff productivity yang mana terdiri dari 3 domain (PO, AI, dan DS) maka dapat di simpulkan bahwa tingkat kematangan tata kelola teknologi informasi di pandang dari internal perspective adalah sebagai berikut: 1). Tingkat kematangan pada kelompok Domain PO masih berada pada level 
rata-rata 2.31 (repeatable). Untuk dapat mencapai tingkat kematangan yang diinginkan (expected maturity level) di level 3 (defined process) maka semua prosedur yang disyaratkan di tiap proses harus dipenuhi.

2). Tingkat kematangan pada kelompok Domain AI masih berada pada level rata-rata 2,46 (Adhoc). Untuk dapat mencapai tingkat kematangan yang diinginkan (expected maturity level) di level 3 (defined process) maka semua prosedur yang disyaratkan di tiap proses harus dipenuhi.

3). Tingkat kematangan pada kelompok Domain DS masih berada pada level rata-rata 2.40 (repeatable). Untuk dapat mencapai tingkat kematangan yang diinginkan (expected maturity level) di level 3 (defined process) maka semua prosedur yang disyaratkan di tiap proses harus dipenuhi.

Secara keseluruhan dapat disimpulkan bahwa tatakelola teknologi informasi untuk Domain Improve and maintain operational and staff productivity Pada STMIK AKBA Makassar berada pada level 2 atau repeatable.

\subsection{Saran}

Beberapa usulan yang berkaitan dengan pencapaian hasil yang optimal dari penerapan Framework Cobit pada Audit Tata Kelola Teknologi Informasi di STMIK AKBA Makassar ini antara lain sebagai berikut:

1). Memilih dan memastikan dipergunakannya standar. Dalam arti kata bahwa seluruh infrastruktur teknologi dan sumber daya yang diadakan, diterapkan, dikembangkan, dan dipelihara haruslah mengikuti standar yang telah dipilih dan ditentukan.

2). Mengawasi perubahan teknologi. Suatu aktivitas kontinyu dan berkesinambungan melihat bagaimana teknologi yang dipilih berkembang di dalam maupun di luar organisasi (evolusi).

3). Mengembangkan dan memelihara kerangka serta lingkungan kendali terhadap seluruh pengelolaan teknologi informasi yang ada dalam wilayah kerja institusi.

4). Mengembangkan dan memutakhirkan berbagai kebijakan internal terkait dengan manajemen dan pemanfaatan teknologi informasi.

5). Mengkomunikasikan obyektif teknologi informasi dan mensosialisasikan keberadaan kontrol untuk mengendalikan keberadaannya.

6). Buat klasifikasi (keparahan dan dampaknya) dan prosedur eskalasi (fungsional dan hierarkis).

7). Mendeteksi dan insiden catatan / permintaan layanan / permintaan informasi.

\section{Daftar Pustaka}

[1] Alexander Setiawan(2008). Evaluasi Penerapan Teknologi Informasi Di Perguruan Tinggi Swasta Yogyakarta Dengan Menggunakan Model Cobit Framework, SNATI 2008, Yogyakarta.

[2] Alvin A, Arens, James K. Loebbecke.(2003). Auditing, Edisi Indonesia, Jakarta.

[3] Amnah,(2012), Audit Sistem Informasi Pada Perusahaan Dagang Aneka Gemilang Bandar Lampung Menggunakan FRAMEWORK COBIT 4.1, Jurnal Informatika, Vol. 12, No. 2.

[4] Ardi Hamzah(2006) Seminar Nasional Aplikasi Teknologi Informasi 2006 Tatalaksana Teknologi Informasi Metode Cobit, SNATI 2006, Yogyakarta.

[5] Bagus Apri Susandi (2014), “Audit Tata Kelola Teknologi Informasi Menggunakan COBIT 4.1 Pada PTPN 
VII Unit Usaha Betung”, Jurnal Teknik Informatika Universitas Bina Darma, Palembang.

[6] Diema Hernyka Satyareni, Fia Mahanani, (2004), Audit Sistem Informasi Akademik Perguruan Tinggi (PT) XYZ Menggunakan Kerangka Kerja COBIT 4, Yogyakarta.

[7] Gatot (2016) "Audit Tata Kelola Produktivitas Operasional dan Staf (Studi Kasus : Distrik Navigasi Kelas I Makassar)", Journal Speed - Sentra Pendidikan Engineering dan Edukasi, Voleme 8 No.1.

[8] Hasibuan, Z. A., (2007), Metodologi penelitian pada bidang Ilmu komputer dan teknologi Informasi, Universitas Indonesia.

[9] Henczel, Susan. (2001)., The Information Audit: a Practical Guide. Munchen: Saur.

[10] IT Governance Institute (2003), IT Governance Implementation Guide: "How do I use COBIT to implement IT governance?", IT Governance Institute, Illinois.

[11] Jusuf, Heni (2009), "IT Governance Pada Layanan Akademik On-line di Universitas Nasional Menggunakan COBIT (Control Objectives for Information and Related Technology) Versi 4.0", SNATI 2008.

[12] Megawati , Fauzi Amrullah.,(2014), Evaluasi Tingkat Kematangan Teknologi Informasi Dengan Menggunakan Model Maturity Level COBIT 4.1 (Studi Kasus PT. BRI CABANG BANGKINANG), Jurnal Sains, Teknologi dan Industri, Vol. 12, No. 1.

[13] Nurhayani.,(2013), Perancangan Tata Kelola Teknologi Informasi Pada Layanan Akademik di Amik Sigma Palembang Menggunakan Analisis SWOT dan COBIT, ISSN 2303-5786.

[14]Pederiva A, (2003), The CobIT, Maturity Model in a Vendor Evaluation Case " Journal of
Information System Audit, Vol. 3 ISACA, USA.

[15]Roes Setiyadi, Mas Wigrantoro (2003), "Pemanfaatan Teknologi Informasi Dalam Penerapan Good Governance di Indonesia", Seminar Paradigma Good Governance di Era Informasi yang Kompetitif, Demokratis dan Transparan, Universitas Gunadarma.

[16] Syukhri,(2013), "Evaluasi Tingkat Kematangan Proses Deliver and Support Pada Implementasi Sistem Informasi Akademik Universitas Negeri Padang Berdasarkan Kerangka Kerja COBIT 4.0", Tesis, Program Pascasarjana Fakultas Teknik, Universitas Negeri Padang.

[17] S.Gondodiyoto,(2007), "Audit Sistem Informasi Lanjutan", Jakarta : Mitra Wacana Media.

[18] Sepita Sari, Syahril Rizal, Rusmala Santi,(2014), Penerapan FRAMEWORK COBIT 5 Pada Audit Tata Kelola Teknologi Informasi Di Dinas Komunikasi Dan Informatika Kabupaten OKU, Jurnal Teknik Informatika Universitas Gunadarma.

[19]Surendro, Kridanto (2009), Implementasi Tata Kelola Teknologi Informasi, Informatika, Bandung.

[20] Setiawan, Alexander (2008), "Evaluasi Penerapan Teknologi Informasi di Perguruan Tinggi Swasta Yogyakarta Dengan Menggunakan Model COBIT Framework", SNATI 2008.

[21] Supangkat, Suhono Harso (2006), "Pengembangan Metode Pengukuran Sistem IT (Kasus: Perguruan Tinggi di Indonesia)", Prosiding Konferensi Nasional Teknologi Informasi dan Komunikasi untuk Indonesia, Institut Teknologi Bandung.

[22] Van Grembergen, Wim, et al,(2004), Structures, Processes and Relational Mechanisms for IT Governance" in Strategies for Information Technology Governance, Idea Group Publishing . 